2016 Global Marketing Conference at Hong Kong Proceedings: 436-437 (July 2016) http://dx.doi.org/10.15444/GMC2016.04.06.04

\title{
WHAT IF THE CEO IS PERCEIVED AS A CORPORATE PSYCHOPATH? THE EFFECTS OF PERCEIVED CORPORATE PSYCHOPATHY ON PRODUCT, STOCK AND EMPLOYER ATTRACTIVENESS
}

\author{
Carmen-Maria Albrecht, University of Mannheim, Germany ${ }^{1)}$ \\ Ariana Stephanie Dominique Finkel, Baden-Wuerttemberg Cooperative State \\ University Mannheim, Germany ${ }^{2)}$ \\ Katja Nothhelfer, University of Mannheim, Germany ${ }^{3)}$
}

\begin{abstract}
Many corporate brands are strongly associated with the person the companies are headed by (Argenti \& Druckenmiller, 2004). Attention for corporate psychopaths (CPs), defined as individuals who show psychopathic traits and work successfully in corporations, has been growing lately (Boddy, 2005). Psychopathic traits (e.g. charm, lack of remorse and empathy) can easily be interpreted as leadership characteristics (e.g. charisma and decisiveness) and therefore boost the career of the psychopath allowing him/her to climb up the corporate ladder (Boddy, 2011). Empirical evidence-although limited-supports this assumption. It has been found that CPs more frequently have senior level positions in organizations than junior ones (Boddy, Ladyshewsky, \&Galvin, 2010b) and that the chances of finding a psychopath among CEOs is four times higher than in the general population (Bercovici, 2011).
\end{abstract}

A CP in a high level position (e.g. a CEO) can not only be assumed to have the largest leverage on how the company's resources are deployed, but the way s/he is perceived by others also has a great impact on the company's image (McGrath, 1995). The willingness to trust an entity is "based on the expectation that the other party will perform a particular action important to the trustor, irrespective of the ability to monitor or control that other party" (Mayer, Davis, \& Schoorman, 1995). Therefore, the perception of negative/psychopathic traits in a CEO is of considerable importance to organizations because it influences the CEO's public image and subsequently the level of trust placed in the top manager. This, in turn, can have far-reaching consequences for the company he works for because an executive's greatest capital consists in the trust placed in him/her and a company cannot be successful in the long run without the trust from stakeholder groups (Hage, 2012). The perception of psychopathic traits can thus have severe consequences for the company's attractiveness to its stakeholders.

The current research investigates the effects of perceived psychopathy of CEOs for the attractiveness of any form of interaction with the company. Results of a structural equation model based on a survey among 670 participants show that perceived corporate psychopathy negatively influences perceived trust in the CEO. Perceived trust in the CEO, in turn, has a positive effect on perceived attractiveness of products, of shares, and of perceived employer attractiveness. Furthermore, if an individual

\footnotetext{
1) carmen-maria.albrecht@bwl.uni-mannheim.de

2) ariana.finkel@dhbw-mannheim.de

3) katja_nothhelfer@web.de
} 
considers sustainability to be of high importance, the ethical standards concerning sustainable behavior seem to be stricter because the trustor cares about them more than the economic aspects of how the CEO manages the company. Therefore, it was found that attitude toward sustainability moderates the relationship between perceived corporate psychopathy and perceived trust in the CEO.

Keywords: corporate psychopath, CEO, corporate branding, reputation, trust, attractiveness of products, attractiveness of shares, employer attractiveness, sustainability

\section{References}

Argenti, P. A. \& Druckenmiller, B. (2004). Reputation and the Corporate Brand. Corporate Reputation Review, 6, 4, 368-374.

Boddy, C. R. (2005). The implications of corporate psychopaths for business and society: An initial examination and a call to arms. Australasian Journal of Business and Behavioural Sciences, 1, 2, 30-40.

Boddy, C. R. (2011).The Corporate Psychopaths Theory of the Global Financial Crisis. Journal of Business Ethics, 102 (2), 255-259.

Boddy, C. R., Ladyshewsky, R. K. \& Galvin, P. (2010).Leaders without Ethics in Global Business: Corporate Psychopaths. Journal of Public Affairs, 10, 121-138.

Hage, S. (2012). Vertrauen ist das größte Kapital. manager magazin. Retrieved from http://www.manager-magazin.de/unternehmen/industrie/a-810049. html].

Mayer, R. C., Davis, J. H. and Schoorman F. D. (1995). An Integrative Model of Organizational Trust. Academic Management Review, 20, 709-734.

McGrath, J. T. (1995). The CEO as Image Maker. Chemtech, 25, 48-52. 